\title{
Children's Constitutional Right to Respect for Family Life in Norway: Words or Real Effect?
}

\author{
Lena R.L. Bendiksen
}

Children`s right to respect for family life is widely recognised in Norwegian law. The specific provision on children's human rights in the Norwegian Constitution, section 104, mentions family. In addition, section 102 states that everyone, including children, have a right to respect for private and family life. The Convention on the Rights of the Child (CRC) and the European Convention on $\mathrm{Hu}^{-}$ man Rights (ECHR), in article 8, have strongly influenced both provisions. The CRC and the ECHR are both incorporated into Norwegian law, and both have a semi-constitutional status, since they take precedence over conflicting domestic legislative provisions. ${ }^{1}$ Children's right to respect for family life is recognised both at a constitutional and a semi-constitutional level. In many specific aspects, domestic statutory law also recognises children's rights in this context.

The aim of this chapter is to introduce and discuss some questions concerning the protection of children's right to respect for family life in Norway. To do this, I will first give a brief overview of some of the legislative protection given. Thereafter, the main objective is to examine whether the constitutional reform in 2014 strengthened the protection children already had through semiconstitutional and domestic statutory law, and to examine whether children's right to family life is given proper attention both in the legislation and case law. I will examine some aspects regarding the establishment of family, children in post-divorce families and children in foster care. Finally, I will discuss the approach the European Court of Human Rights (ECtHR) has assumed in two recent cases concerning children's right to family life in Norway. The aim is not to discuss the notion of family, the protection of family life in general, nor the potential tension between the right to family life versus the right to privacy and private life.

1 Act relating to the strengthening of the status of human rights in Norwegian Law (The Human Rights Act) of 21 May 1999 no. 30 (Menneskerettsloven), sections 2 and 3. 
Section 104 of the Norwegian Constitution does not directly protect children's right to respect for family life, even though family is mentioned in the provision.

Section 104, subsection three of the Constitution states: 'Children have the right to protection of their personal integrity. The authorities of the state shall create conditions that facilitate the child's development, including ensuring that the child is provided with the necessary economic, social and health security, preferably within their own family'.

According to the last sentence, the main objective of the provision is to ensure the child's development. To do so, the child is entitled to necessary economic, social and health security, 'preferably within their own family'. To protect the child's family or family life is not the particular purpose, but more a means to ensure the child's development through economic, social and health security. This security should, according to section 104, preferably be facilitated within the child's family. By this, the Constitution confirms the family as children's primary caregivers, without defining a family or enshrining a right to family life for children. The discussions in the preparatory works of the Constitution, which are a key tool for interpretation, show that family by intention was not defined. ${ }^{2}$ The preparatory works states that the sentence 'preferably within their own family' has to be interpreted in the context of the best interest's principle and the child's right to participate in general. ${ }^{3}$ In addition, the preparatory works states: 'preferably within their own family' is not to be read as an assumption of the parents' rights to precede the best interests of the child. ${ }^{4}$ Overall, this subsection of section 104, and the discussion in the preparatory works, indicates that the reference to family in section 104 primarily underlines the notion of a family and does not, as such, protect the right to family life. In a similar way to the CRC preamble, the aim seems to be to acknowledge family as the fundamental group of society and the natural environment for the growth and well-being of children. On its own, section 104 of the Constitution does not highlight children's right to respect for family life, nor the more

2 Dokument 16 (2011-2012) Rapport til Stortingets presidentskap fra Menneskerettighetsutvalget om menneskerettigheter i Grunnloven (19 December 2011) 194 (Dok. 16). Report from the Human Rights Commission to the Presidium of the Parliament on human rights in the Constitution. The report is available only in Norwegian <https://www.stortinget.no/Global/ pdf/Dokumentserien/2011-2012/dok16-201112.pdf> accessed 25 January 2019.

3 Dok. 16 (n 2) 194-195.

4 Innst. $186 \mathrm{~S}$ (2013-2014) Innstilling til Stortinget fra Kontroll- og konstitusjonskomiteen 31. 
specific right to maintain a personal relationship and direct contact with both his or her parents like the CRC article 9, subsection 3, or the EU Charter of Fundamental Rights section 24, subsection 3.

Section 102 of the Norwegian Constitution addresses the right to respect for family and private life as follows: Everyone has the right to the respect of their privacy and family life, their home and their communication. Search of private homes shall not be made except in criminal cases. The authorities of the state shall ensure the protection of personal integrity'.

'Everyone', including children, has the right to respect of their family life, and the wording of section 102 is very similar to the ECHR article 8 (1). Still, a difference is that while the constitutional provision seems absolute, ECHR article 8 (2) includes a reservation. As discussed by Haugli, the constitutional preparatory works includes a discussion whether one should include some kind of reservations, but no reservation was in fact included. ${ }^{5}$ Still, according to the Supreme Court, the constitutional protection cannot be - and is not absolute. In accordance with ECHR section 8 (2), any restriction on the constitutional rights and freedoms must be in accordance with the law, must pursue a legitimate aim and must be necessary and proportionate, even if this is not stated explicitly. ${ }^{6}$

Thus, the Norwegian Constitution acknowledges children's right to respect for family life through section 104 combined with section 102 .

Sections 102 and 104 in the Constitution are both in conformity with, among others, ECHR article 8 and several articles in the CRC. According to the Supreme Court, both section 102 and 104 must be understood 'in the light of' their international background. ${ }^{7}$ Still, this must be done in a way where the responsibility to interpret, clarify and develop the Constitution's human rights provisions in the future, is a national responsibility held by the Norwegian Supreme Court. Case law from the ECtHR and other international bodies, are therefore taken into serious consideration when interpreting and applying the Constitution, at the same time as the Supreme Court has the main responsibility to interpret the Constitution. ${ }^{8}$

5 Trude Haugli, 'Constitutional Rights for Children in Norway' in Trude Haugli and others (eds), Children's Constitutional Rights in the Nordic Countries (Brill 2019).

6 HR-2014-2288-A (28) and HR-2015-206-A (6o).

7 HR-2015-206-A (57) and (64).

8 Arnfinn Bårdsen, 'Interpreting the Norwegian Bill of Rights' (Annual Seminar on Comparative Constitutionalism, Oslo, November 2016) <https://www.domstol.no/en/Enkelt-domstol/ -norges-hoyesterett/Articles/articles-and-speeches-2016/interpreting-the-new-norwegianbill-of-rights/> (21) accessed 25 January 2019. 
The CRC contains a cluster of rights in relation to the integrity of the family unit, and the State's obligation to both support families and provide alternative care where the family environment has failed to function in the best interests of the child. According to the CRC article 7 , the child has the right to "know and be cared for by his or her parents' and, in addition, article 9 states that parties shall ensure 'that a child shall not be separated from his or her parents against their will', except when necessary and in accordance with the law and procedures. No child shall be subjected to 'arbitrary or unlawful interference with his or her privacy, family, home or correspondence', according to article 16. Other articles, such as articles 8 and 9, subsection 3, addresses children's rights to preserve family relations and their rights to maintain personal relations and direct contact with both parents. The Committee on the Rights of the Children has interpreted the term 'family':

The family is the fundamental unit of society and the natural environment for the growth and well-being of its members, particularly children (preamble of the Convention). The right of the child to family life is protected under the Convention (art 16). The term "family" must be interpreted in a broad sense to include biological, adoptive or foster parents or, where applicable, the members of the extended family or community as provided for by local custom (art 5$) \cdot{ }^{9}$

Article 8 of the ECHR also states that everyone has the right to respect for his/ her private and family life, his/her home and his/her correspondence. The ECtHR has repeatedly stated that 'the mutual enjoyment by parent and child of each other's company constitutes a fundamental element of family life.' ${ }^{10}$ Both the CRC and the ECHR involve rights between a child and his or her family. The rights included in the conventions protect the parents or the family as the child's primary caregivers and protects the child in the family. In addition, the provisions protect children from their family, and gives some kind of protection to children without at family. These are some of the international background sections 102 and 104 of the Constitution must be understood in the light of.

9 UN Committee on the Rights of the Child, General comment No. 14 (2013) on the right of the child to have his or her best interests taken as a primary consideration (art 3 , para 1) (29 May 2013) $\mathrm{CRC} / \mathrm{C} / \mathrm{GC} / 14$ para 59 .

Among others, Johansen v Norway (1996) ECLI:CE:ECHR:1996:0807JUDoo173839o. 


\section{$3 \quad$ Constitutionalising-Any Essential Legal Effect?}

Sections 102 and 104 stating the constitutional rights pertaining children's family life in Norway represent no innovation. They are more a constitutional confirmation of rights already recognised and given to children throughout international law and to some degree, already expressed and implemented in the Children Act ${ }^{11}$ and the Child Welfare Act. ${ }^{12}$ For instance, maintaining a close relationship with both parents after a divorce is a key argument in case law concerning custody, residence and contact. Both the Children Act and the Child Welfare Act grant children a right to maintain contact with the nonresidential parent or both parents if placed in alternative care, for example, in a foster home. ${ }^{13}$ Still, it must be mentioned that the Children Act does not use the term 'family', and the Child Welfare Act barely uses the term.

The recognition of children's rights in the Constitution is important. In my opinion, sections 102 and 104 in the Constitution strengthen the close link between the best interests of the child and the right to respect for family life. By declaring sections 102 and 104 as complementary, the Supreme Court has emphasized the interlinkage between private and family life and the best interests of the child. Furthermore, the Supreme Court have stated that the interests of the child is to be included as an element given considerable emphasise in the proportionality assessment pursuant to section 102 of the Constitution. ${ }^{14}$

In theory, both the constitutionalizing of the right to respect for family life, and the interpretation made by the Supreme Court stating sections 102 and 104 as complementary, could have significant impact. It might cause more focus on children's rights to respect for family life, as opposed to the parents' rights in this matter. In some cases, the child and the parent(s) have a mutual interest in the protection of their shared family life. Still, it is important to highlight the child's interests and rights distinctly. At other times, the child's right to family life is contrary to the parent(s) respective right. In all cases, a stricter scrutiny of whether the child's rights to respect for family life is emphasised enough when the best interests of the child are considered, might be required. It is not

11 Act relating to Children and Parents (The Children Act) of 8 April 1981 no. 7 (Lov om barn og foreldre). An unofficial English translation is available at $<$ https://www.regjeringen.no/en/dokumenter/the-children-act/id448389/> accessed 25 January 2019.

12 Act relating to child welfare services (Child Welfare Act) of 17 July no. 100 (Lov om barneverntjenester). An unofficial English translation is available at <https://www.regjeringen .no/en/dokumenter/the-child-welfare-act/id448398/> accessed 25 January 2019.

13 The Children Act (n 11) section 42 and Child Welfare Act (n 12) section 4-19.

14 HR-2015-206-A (66). 
possible to examine or answer precisely whether the constitutionalizing has had effect in this matter. Still, I will examine some areas of child law, looking for the standing of the child's right to respect for family life, and looking for a possible change or development promoted by the constitutionalizing. The analysis of case law below will partly examine whether the constitutionalizing has had any impact.

Establishment of the Child's Family

Neither children nor adults have the right to a family as such. For example, the existence of family life determines the applicability of the ECHR, article 8. Both the positive obligations to secure enjoyment of family life and the negative obligation to refrain from taking action that interferes unjustifiably with family life, rely on the existence of family life. Likewise, the CRC does not give children a right to a family as such. Article 20 of the CRC states that a child temporarily or permanently deprived of his or her family environment, is 'entitled to special protection and assistance provided by the State', but not a new family. Still, the right to know and be cared for by his or her parents and the right to preserve family relations as recognised by law are important for the existence of family life. Hence, the establishment of paternity and maternity for children are important in this matter.

The Children's Act regulates the establishment of paternity and maternity for children. A woman who has given birth to the child is regarded as the mother, while paternity or co-maternity is established through marriage (section 3), declaration (section 4) or judgment (section 9). Regarding the possibility to contest and legally have the paternity changed, the act has been amended several times. The last amendment came in 2016 when, again, the time limits for initiating paternity cases was removed. According to section 6 , 'the child, either of the parents and any person who believes that he is the father of a child who already has a father, may at any time bring an action in the courts regarding paternity, established through marriage or declaration'. According to the preparatory works, the rationale for amending the law was that knowing the biological origins of the child is important for both the child and the parents. It might be argued that it is not in the child's best interests nor in accordance with the child's right to respect for family life to have the paternity changed after several years. Still, some efforts have been taken to protect the child. According to section 6 a, a child aged 18 or older has the right to obtain information on the identity of his or her biological father, without this involving a contestation of paternity. However, access to information does 
not guarantee that the parent will refrain from bringing a paternity action according to section 6 .

For assisted reproduction, a person who consents to the mother-to-be being treated is considered the father or co-mother either by marriage, declaration or judgment. The consent then replaces the genetic link. The rule applies only when the assisted reproduction has been conducted in accordance with Norwegian law. According to the Biotechnology Act section 2-7, the child from age 18 has a right to know the sperm donor's identity. ${ }^{15}$ Consequently, the Biotechnology Act sections 2-8 and 2-9 states that all sperm donors have to register in a donor register and cannot be anonymous. The child is the only person allowed to receive this information. Neither the parents nor the donors are at any stage allowed to gain information about each other's identity.

Adoption can change both legal paternity and maternity. ${ }^{16}$ According to the Adoption Act section 9, an adoption may not be granted without the consent of the child, if the child is aged 12 years or older. Younger children only have the right to express his or her views in this matter. Step-parent adoption is in some occasion allowed, but the step-parent should normally have cared for the child for five years before this could take place, section 16. This to ensure that the adoptive parent actually have acted as a social parent for the child, and with that safeguarding that a step-parent adoption actually combine the social and legal parenthood for the child.

Of course, the child, from the age 18 , has an unconditional right to know who his or her originally parents are, and the child will be informed, in writing, by the adoption authority about this right at the age of $18 .{ }^{17}$ In the preparatory works it was suggested to decrease the age limit for the child's right to know, from age 18 to age 15 . Rationale behind the suggestion was the importance for the development of the child's personality and a wish to get better compliance in the legislation concerning age limits for children. ${ }^{18}$ This suggestion was turned down, arguing the strain this may cause children. ${ }^{19}$ Even though the adoption act entered into force recently, July 2018, it cannot be said that the constitutionalizing of children's right to respect for family life, have had a

15 Act relating to the application of biotechnology in human medicine, etc of 5 December 2003 no. 100 (Lov om humanmedisinsk bruk av bioteknologi m.m.).

16 Adoption Act 16 of 16 June 2017 no. 48 (Lov om adopsjon).

17 Adoption act (n 16) section 39.

18 NOU 2014:9 Ny adopsjonslov section 23.3.3; Prop.88 L (2016-2017) Lov om adopsjon (adopsjonsloven) section 20.5.

19 Innst.359 L (2016-2017) Innstilling fra familie- og kulturkomiteen om Lov om adopsjon (adopsjonsloven) 10-11. 
significant impact on the new legislation. This aspect of children's rights is neither a dominant argument in the preparatory works, nor in the new legislation.

\section{5 Children's Right to Family Life with Both Parents in Post-Divorce Families}

For some years, there has been an ongoing discussion about equality in parenthood, and the child's right to both his or her parents in post-divorce families in Norway. The agenda has been obvious: more equality between parents. I would like to argue that these discussions have been focusing more about the rights of the parents than children's rights. This does not only occur in the political debates, in media, etc. but also when it comes to legislation. I will look into some of the latest amendments to substantiate my arguments.

Under the heading 'equal parenting' some amendments in the Children's Act entered into force in January 2018. In section 30, it is explicitly mentioned that parents shall exercise joint parental responsibility by making decisions jointly. This amendment only represents a codification, but still the goal is to highlight equal parenting even more. In addition, amendments have been made to section 36 , so joint custody in the wording is mentioned as an alternative before sole custody, not after. This holds in reality no substantive change, but is an additional attempt to emphasize equal parenting. The time limit for the duty to notify the other parent of intentions to relocate with the child was changed from six weeks to three months prior to moving. ${ }^{20}$ The duty to notify applies when contact has been agreed or determined, and the aim is to get parents to discuss and make arrangements concerning contact after the relocation as well. The most controversial change is made in section 35. Current law states that the mother has sole custody if the parents are not married or cohabiting. After the amendment enters into force, all parents, will have joint parental responsibility for children regardless of marriage or cohabitation. Parents who do not wish to have joint custody have to register within a year after the child was born. Otherwise, they will automatically have joint custody. The changes to section 35 have not entered into force yet, and it is not decided when it will.

It is questionable whether these recent amendments are influenced, or reasoned by, the constitutionalizing of children's right to respect for family life. The preparatory works do not mention children's right to respect for family life 
at all. ${ }^{21}$ Section 104 of the Constitution is barely mentioned, and then only focusing on the child's best interests and their right to participation in decisionmaking. Section 102 of the Constitution is not mentioned. The only CRC article mentioned explicitly is 12 , but it is also stated that the best interests of the child is the guiding principle of the CRC. The starting point of the Government bill is, however, that children have a right to two parents. This statement is not supported by the Constitution, the CRC or other conventions. The only reference given is to the the political platform for the (current) Norwegian Government, stating that the government will try to equate parents as caregivers, with the same rights, and, at the same time, ensuring the best interests of the child in matters of child custody and access. ${ }^{22}$ This is supported in part 2.1 of the Government bill, where it is argued that equal parenting implies equal opportunities, and the feeling of equivalence. The preparatory works contain no direct references to children's right to family life in general. Thus, improving children's rights was not a driving force for the amendments. Rather, the main rationale seems to be to enhance the equality between parents.

One may argue that parents, mediators, lawyers or even judges can hardly be expected to consider children's right to respect for family life in depth, if the law and the legislator does not emphasise the duty to do so, particularly, when the laws are amended and new laws enacted.

Still, there might be some positive changes in the writing of conclusions in judgments. Even though the Children's Act have a specific provision stating the child's right to contact with both parents, section 42, the most common way to write a conclusion on this matter, is by stating that the parent has a right to contact with the child in a specific way. This is done even though section 42 is mentioned, but seldom discussed, in the decision. Some examples are examined below.

In HR-2007-1101-A, the question presented by the Supreme Court in the judgment paragraph 1 was that 'the case concerns the question of right to access for the father to his nine-year-old daughter'. The unanimous conclusion was in section 46 written in the terms of ' $\mathrm{B}$ (the father) has the right to access to his daughter as stated in this judgment'.

In a similar way the question presented by the Supreme Court in HR-2010304-A paragraph 1, was whether the parent who does not live with his daughter should have contact with her. The unanimous conclusion was written in

21 Prop.161 L (2015-2016) Endringer i barnelova mv. (likestilt foreldreskap) and Innst.195 L (2016-2017) Innstilling fra familie- og kulturkomiteen om Endringer i barnelova mv. (likestilt foreldreskap). 
the terms of 'A (the father) shall have the right to contact with $\mathrm{C}$ as follows', paragraph $5{ }^{2.23}$

It might be argued that this is a consequence of children's lack of legal and de facto autonomy and, in particular, lack of participation rights in court proceedings. I would argue that because of this, it is even more important that the court decision highlight the rights children have in this matter. Making sure that the child's right is mentioned in the conclusion, ('the child and the mother/father have the right to contact as stated below'), could cause a more in-depth examination of the child's rights in this matter. In my opinion, it is not enough to mention the Children's Act section 42, this must be discussed in light of the present case, and in the light of the Constitution and the CRC.

Reading some decisions from the Court of Appeal (Lagmannsretten) might show a positive development. In some cases, the decision is now written in terms of either stating which right the child has to contact with the parents or by stating the child and the parents right to contact with each other. ${ }^{24}$ Still, this is by no means consistently done.

Right to Family Life for Children in Foster Care

Children's right to respect for family life within the child welfare system in Norway could be discussed from many different points of views. I will only discuss a few.

Children's right, when separated from one or both parents, to maintain personal relations and direct contact with their parents on a regular basis could be discussed based on the amount of contact often decided in childcare cases. One side of this is the contact between the child and persons other than his or her parents. According to The Child Welfare Act section 4-19, contact between the child and relatives or other persons to whom the child is closely attached, may only be decided if one or both of the parents is/are dead, or if it is decided that there should be no or very limited contact between the child and one or both parents. No or 'very limited contact' with parents is a precondition to be able to grant a child under public care the right to contact with for instance siblings, grandparents or former foster parents. It might well be argued that this is contradictory to the child's right to respect for family life. As mentioned The Committee on the Rights of the Children has stated that the term 'family'

23 For other examples, see HR-2011-2244-A and HR-2005-853-A.
24 See, eg, LF-2018-24631 and LE-2017-1800oo. 
must be interpreted in a broad sense, and, in addition, that the right to maintain personal relations and direct contact 'also extends to any person holding custody rights, legal or customary primary caregivers, foster parents and persons with whom the child has a strong personal relationship.25

A 2016 government report on reform of the Child Welfare Act, explicitly discussed the child's right to respect for family life in this matter. ${ }^{26}$ In the report, it is argued that the limitations on the possibility to grant the child contact with the extended family is hardly in accordance with section 102 in the Constitution, ECHR article 8 and CRC article 16. The report recommends that the child should be given a right to contact with parents, siblings and others closely related to the child. The reasoning behind this being that a change like suggested would bring The Child Welfare Act in better compliance with the right to family life according to the Constitution, CRC and ECHR. ${ }^{27}$ The constitutionalizing of children's right to family life was a part of the reasoning for the recommendation, but so was the CRC and ECHR as well.

Another question concerning contact between the child and people other than the parents is the interpretation of 'very limited' contact. As mentioned, contact between the child and people other than the parents can only be granted if one or both of the parents are dead or the contact between the child and the parents are denied or 'very limited'. The Supreme Court has, in two judgments, discussed what should be regarded as 'very limited' contact between parents and children after foster placement.

In HR-2011-2269-A it is stated that a former foster mother's claim to have contact with the former foster child was admissible. The contact between the child and mother was set to two hours, three times a year, and this was regarded as 'very limited'. In HR-2015-964-A, a child's grandmother wanted contact with her grandchild placed in foster care. The Supreme Court stated that contact between parent and child, regulated to two or three hours, four times a year, was not regarded 'very limited'. Contact between a child and his or her parents is, accordingly, looked upon as very limited if it is two hours, three times a year, but not if it is two hours, four times a year. I would like to argue that contact between a child and a parent, or someone else close to the child, for eight hours a year hardly can be understood as anything but very limited.

25 Committee on the rights of the child, General comment No. 14 (n 9) section 6 o.

26 NOU 2016:16 Ny barnevernslov. Sikring av barnets rett til omsorg og beskyttelse (NOU 2016:16) 181-182. 
Still, the contact between a child in foster care and his or her parents are often limited. The Supreme Court often set the contact in cases regarded as long-term placements, to three to six times a year and only a few hours each time. ${ }^{28}$ It could be asked what kind of respect for family life, meeting your parents around ten hours per year is? It cannot be said that the constitutionalizing of the right to family life has made a notable impact on decisions in this matter. On the other hand, the 2016 government report on reform of the Child Welfare Act recommended changes here as well. The report thoroughly discusses the limited contact often set in these cases. It is recommended that the system for contact is changed from 'giving contact rights' to a system where restrictions in contact must be reasoned. The starting point being giving children a general right to contact with parents, siblings and other close to the child. In addition, restrictions may be set, if necessary and in the best interests of the child. ${ }^{29}$ The recommendations are still under discussion, and no amendments to the act has been made in this matter. It is expected that amendments or a brand new Child Welfare Act will be suggested in 2019.

In the same way as mentioned about children's rights in post-divorce families, it could be discussed if children's rights are the focus or even a focus when contact rights are discussed in these cases. I would argue that this is normally not the case. The most common way to write conclusions in judgments concerning contact between a child and his or her parents is still by stating that the parent has a right to contact with the child, still this is not consistently done. Some examples could be examined.

The conclusion in the Court of Appeals judgment LA-2018-6934 is written in terms of $A$ and $B$ shall have contact with $C$ four times a year, $C$ being the child, A and B the parents. The judgment has no mention of the term 'family life' and the Constitution, in sections 102 and 104, is not mentioned. On the other hand, the conclusion in LB-2018-53823 is written in terms of C had the right to contact with $A$ and $B$ four times a year, two hours each time. $C$ being the child, A and B the parents. 'Family life' or the Constitution, section 102 is not mentioned in the judgment. The court mentions the Constitution, in section 104, when arguing that foster placement is in the child's best interests, but not when arguing the right to contact.

The Supreme Court judgment in HR-2017-2015-A should be mentioned as well. The question was whether all contact between parents and child should be denied. The parents had exposed the baby boy to serious violence before

\footnotetext{
28 NOU 2016:16 (n 26) 185.

29 NOU 2016:16 (n 26) 188-189.
} 
the care order was made. The judgment is discussed by Sandberg. ${ }^{30}$ The Supreme Court decided in favour of supervised contact one hour, once a year between the boy and his parents. Many elements of this judgment could be discussed. I concur with Sandberg that the abuse of the child formed exceptional circumstances and reasoning to deny all contact. Another question is whether contact one hour each year by any means could be called family life. Still, I would like to point out that the approach in the judgment represents, in my view, a good development, even though the conclusion hardly is. When discussing the contact between a three-and-a-half-year-old boy living in a foster home and his parents, the Supreme Court argues based on the child's right to family life, not only the parents' rights. This is an approach seldom seen in this kind of judgments. The Supreme Court argues that the boy has a right to family life, and both the Constitution, ECHR and different articles in CRC are mentioned in this matter. Both sections 102 and 104 in the Constitution are discussed, and, in particular, the connection between these sections are taken into account. The approach in the judgment represents, in my opinion, a good development, and even though the judgment includes discussions of sections 102 and 104 in the Constitution, it is not possible to give the constitutionalizing alone the credit for the approach. To do so, all judgment should have been more consistent in this matter. It might still be argued that the constitutionalizing did have an impact.

Other aspects of children in foster care and their right to family life could also be discussed. For instance, it could be argued that children's right to respect for family life in their new foster family is not given proper attention when the Child Welfare Act does not have an opening for long-term placements. A foster home placement is legally always regarded as a temporary measure in Norway. According to the Child Welfare Act, section 4-21 there are still exceptions.

The county social welfare board shall revoke a care order when it is highly probable that the parents will be able to provide the child with proper care. The decision shall nonetheless not be revoked if the child has become so attached to persons and the environment where he or she is living that, on the basis of an overall assessment, removing the child may lead to serious problems for him or her. ${ }^{31}$

\footnotetext{
30 Kirsten Sandberg, 'Best interests of the child in the Norwegian Constitution' in Trude Haugli and others (eds), Children's Constitutional Rights in the Nordic Countries (Brill 2019). 
The 2016 government report on reform of the Child Welfare Act recommended no substantial changes to this provision. ${ }^{32}$ Children's right to respect for family life, according to the Constitution or the conventions, was not argued in this matter in the government report. Adoption is now, and probably in the coming recommendation of amendments to the Child Welfare Law, the only long-term placement possibility. Still, many children actually live their whole childhood in a foster home without adoption for different reasons being an admissible option. Formally, the care order is regarded a temporary measure, but, in reality, the care orders are in many cases planned to be a long-term placement of the child.

Adoption as a measure in the child care system raises a lot of questions. In Norway, adoption without the consent of the parents is an option for some children living in foster homes, according to the Child Welfare Act, section 4-20. Firstly, the parents must be deprived of all parental responsibility. The adoption consent could then be given if the care order is regarded as permanent, adoption is in the child's best interests and the adoption applicants have been acting as and showed themselves fit to bring up the child as their own. In addition, the conditions under the Adoption Act must be satisfied. According to the Child Welfare Act section 4-2O a, contact visits between the child and his or her biological parents after adoption could be set. This could be regarded as safeguarding children's right to respect for family life in these cases. On the other hand, contact visits after the adoption can in accordance with section 4$20 \mathrm{a}$, only be considered if the adoption applicants consent to such contact. In addition, if contacts visits are decided, but does not take place after the adoption, neither the parents nor the child are given any possibility to make the contact happen. If this gives the child a meaningful right could be discussed. I will not discuss adoption of foster children as such, even though I would like to argue that the child's right to family life does not seem to be an essential argument when adoption of foster children is discussed or decided upon. On the other hand, adoption may be regarded as a way of creating a new legal family for the child.

The last three years several applications against Norway have been lodged with the ECtHR in child welfare cases. The main questions in several of the cases communicated, concerns care orders, contact and adoption. Some of the cases have been decided, and I find two of them interesting when discussing children's right to respect for family life. 

by the ECtHR

In a recent case, Jansen $v$ Norway, the ECtHR concluded that there had been a violation of article 8 of the ECHR. ${ }^{33}$

The girl A was born in 2011, and the applicant is her mother. The relationship between A's mother and father ended before A was born, and when A was born her mother lived with her parents who are Norwegian Roma. The mother and child moved back and forth between the mother's family and a parent-child institution, because of threats and violence from the applicant's father - the child's grandfather. The Child Welfare Service then applied for a care order, and then issued an emergency care order to place A in an emergency foster home at a secret address. After three months, A was moved from the emergency foster home to her current foster home, and contact with her mother and father was restricted to supervised contact one-hour per month in suitable premises and with police assistance. The reasoning to both the moving of A, and the contact restrictions, were the risk of child abduction. After a year, the City Court ordered that neither the mother nor the father was entitled to have contact with A. The parents appealed to the Court of Appeals who dismissed the appeal and stated that the main reason for refusing contact was the risk of abduction, but, in addition, the applicant father's serious offences on his criminal record, his threatening to kidnap the child, and death threats against the child's father. Both parents appealed to the Supreme Court. The case was then reheard by the Court of Appeal with the same conclusion and then refused leave to appeal to the Supreme Court.

The mother then complained under article 8 of the ECHR that the domestic authorities had violated her right to respect for her family life by refusing her contact rights with A, since this was neither necessary nor proportionate in the circumstances. Moreover, it effectively prevented A from getting to know her Roma heritage and language. The ECtHR unanimously held that there had been a violation of article 8 of the Convention.

The question examined by the ECtHR was whether refusing the applicant contact with A were 'necessary in a democratic society'. Firstly, the ECtHR stated the best interests of the child as a general principle in paragraph 91. In addition, the court stated how the best interests of the child both must include the child's right to family life, but, at the same time, ensure his or her development in a sound environment. ${ }^{34}$ With references to the court's case law, it was stated

33 Jansen v Norway (2018) ECLI:CE:ECHR:2018:09o6JUDooo282216.

34 Jansen $v$ Norway (n 33) para 92. 
that measures totally deprive an applicant of his or her family life with the child and are inconsistent with the aim of reuniting them should 'only be applied in exceptional circumstances and could only be justified if they were motivated by an overriding requirement pertaining to the child's best interests.' ${ }^{35}$

Applying the general principles to the present case, the court highlighted the dilemma between the alleged danger of abduction and its implications for the contact sessions, versus the potential negative long-term consequences for the relationship between the child and her mother. As to the procedure, the court found the decision-making process comprehensive and that the applicant was sufficiently involved. Regarding the in-depth examination of the case and especially the consideration of the child's best interests, the court in paragraph 100 concluded: 'In the Court's view, there are no grounds for contesting that the domestic authorities carried out a sufficiently in-depth examination of the case or that the decision was taken based on what was considered to be in A's best interests'.

On the one hand, this seems like the ending statement, but the court then asks if the interpretation and application of the notion of the best interests of the child' was compatible with the Court's jurisprudence. In addition, if the guiding principle whereby a care order should be regarded as a temporary measure and the positive duty to take measures to facilitate family reunification were taken into account. The right to respect for family life was then discussed in paragraph 103 .

Furthermore, the decision complained of entailed the danger that family relations between the applicant and A were effectively curtailed (see paragraph go above). In its decision the High Court did not explicitly mention that the applicant and A had not seen each other for three years - subsequent to the few contact sessions that took place after the 'car incident' (see paragraph 12 above). Moreover, the High Court's decision did not focus on reuniting A and the applicant (see paragraph 93 above) or on preparing for reunification in the near future, but rather on protecting A from a potential abduction and its consequences. Taking into account the circumstances of the present case, the Court considers that there was a risk that A could completely lose contact with her mother. According to the Court's jurisprudence it is imperative to consider also the long-term effects which a permanent separation of a child from her natural mother might have (see, mutatis mutandis, Görgülü v 
Germany, no. 74969/o1). This is all the more so as the separation of A from her mother could also lead to an alienation of A from her Roma identity.

While it was held in paragraph 100 that the Norwegian authorities carried out a sufficiently in-depth examination of the best interests of the girl, paragraph 103 emphasises the girls right to family life, and the court stresses that the girl could lose contact with her mother, and this could cause long-term effects. The girl's right to family life is clearly visible in the conclusion as well, in paragraphs 104 and 105.

In conclusion, although the Court accepts that the decisions of the national authorities were made in what they considered to be the best interests of the child and bears in mind that perceptions as to the appropriateness of intervention by public authorities in the care of children vary from one Contracting State to another (see paragraph 95 above), the Court holds that in the instant case, the potential negative long-term consequences of losing contact with her mother for A and the positive duty to take measures to facilitate family reunification as soon as reasonably feasible were not sufficiently weighed in the balancing exercise.

In the light of the above, the Court concludes that there has been a violation of Article 8 of the Convention.

Some might argue that the court first accepts that the Norwegian judgments were based on the best interests of the child and that this examination was done sufficiently, and then in a way sets aside the best interests of the child in favour of the parent's interests. I would, however, argue that this judgment is an example of the ECtHR emphasising the child's right to respect for family life, and the fact that this was not sufficiently discussed or weighed in the Norwegian judgments. In my point of view, the approach taken by the ECtHR highlights the importance of taking children's right to family life into account. ECtHR did not conclude that the Norwegian courts decisions was not based on the child's best interests, they concluded that the examination was incomplete.

The other case I would like to mention is Strand Lobben and others $v$ Norway. ${ }^{36}$ In this case, the court held, by four votes to three, that there had been no violation of article 8. The case was referred to and heard by the Grand Chamber on 17 October 2018. The Grand Chambers ruling in the case have not been made. The judgment discussed below is, therefore, not final. 
The mother in this case turned to the child welfare authorities during pregnancy because she was in a difficult situation, and she applied for a late abortion in her sixth month pregnancy. When the child, $\mathrm{X}$, was born September 2008 , she agreed to stay in a mother and baby care unit. When she withdrew her consent to stay at the care unit, the child welfare authorities decided to take $\mathrm{X}$ into immediate compulsory care and place him in a foster home on an emergency basis. After the placement, the first applicant had weekly half-hour visits with X. The County Social Welfare Board then granted a care order. The mother appealed the decision to the City Court, who overturned the decision. The child welfare authorities appealed to the Court of Appeal and the decision was again overturned. The care order was upheld and the mother did not appeal.

In July 2011, the child welfare authorities requested the County Social Welfare Board to deprive the mother of her parental responsibility for X, and to grant the foster parents' permission to adopt him. The mother then applied for termination of the care order or, alternatively, extended contact rights with $\mathrm{X}$. The foster parents got permission by the County Social Welfare Board to adopt the boy. The mother appealed and the City Court upheld the decision on adoption. Further appeals were denied. The question at stake in the ECtHR assessments was whether the impugned measure was 'necessary in a democratic society'. The majority of the judges summed up their view in paragraphs 129 and 130, and concluded that there had been no violation of article 8 of the Convention.

Three judges had a joint dissenting opinion. After establishing some general principles under article 8 of the ECHR in relation to child placement and adoption, they argued that it had not been demonstrated that these standards had been met in the present case. The minority argued that the majority relied too much on the Aune $v$ Norway case, ${ }^{37}$ when there are fundamental differences between the cases. In addition, the minority gave several statements with context to the child's right to respect for family life. In paragraph $24(2)$ the minority stated the adoption put an end to the legal ties between the mother and the child. The minority finds it extraordinary that the 'foster parents' willingness to contemplate contact 'if the child so wished' is factored into the legal assessment given that this willingness had no legally binding force.

In paragraph $24(4)$ it is added the following:

Nowhere in the file does it emerge clearly that the domestic authorities considered the long-term effects on the child of the permanent and 
irreversible cutting of de facto and legal ties with his biological mother. $\left.{ }^{26}\right]$ The Court has repeatedly held that severing such ties cuts a child off from its roots, which is a measure which can be justified only in exceptional circumstances.

And in paragraph 24 (5) the child's siblings and other family are mentioned, 'In the individual assessment required and the balancing of the interests of the child and the biological parent, nowhere does the severing of X's ties with his other sibling (and subsequently a second sibling) or his grandparents appear to feature'.

In the conclusion, the minority focuses on the need to respect existing jurisprudential standards. They emphasise that standards like exceptional circumstances and to apply stricter scrutiny when breaking of de facto and de jure ties are standards with legal meaning and legal consequences. They then criticise the majority arguing, 'the majority takes cognizance of these legal standards in an abstract manner but only partly applies them to the circumstances of the present case'. In paragraph 28 , the minority concludes by addressing and criticising the procedural focus taken.

The general principles outlined in Section III reflect the case-law as it stands and clearly point to procedural and substantive requirements which must be met in a case like this. Once it comes to the concrete application of those principles to the circumstances of the individual case, it would appear that the focus becomes almost exclusively procedural. However, an excessive focus on procedures risks rendering banal what are far-reaching intrusions in family and private life. In addition, the Court's general principles when read in the abstract risk providing false hopes of reunification which, as this case demonstrates, are unlikely to be fulfilled once a child has been taken into care, access rights have been significantly limited, time has passed and domestic proceedings formally meet Article 8 procedural standards.

The Grand Chamber heard the Strand Lobben case in October 2018. It will be interesting to see the approach the Grand chamber takes, and to what extent the allegation about an 'almost exclusively procedural' focus in these cases will be discussed.

As I read Strand Lobben $v$ Norway, the discordance between the majority and the minority is not about parental rights versus child rights, or biological parents versus psychological parents. It is more about how to apply principles to the circumstances of individual cases and about to what extend the ECtHR 
should assess substantive requirements. I believe both the majority and the minority emphasise the best interests of the child, but the minority highlights the child's right to respect for family life more explicitly.

The Jansen case and the minority in the Strand Lobben case sends, in my opinion, a clear statement. Children's right to family life must be given proper attention when deciding questions concerning among others contact, adoption and care orders. The Grand Chambers ruling in the last case will, of course, be interesting in this matter. Anyway, it is not possible to argue that the judgment and the minority statement in these cases are noticeably influenced by the Norwegian constitutionalizing of children's right to respect for family life. Sections 102 and 104 of the Constitution are both mentioned as part of the relevant domestic law, but are naturally not discussed any further.

\section{$8 \quad$ Concluding Remarks}

As shown, children's right to respect for family life is protected in a number of different sets of rules on a constitutional and semi-constitutional level, and, in addition, on a statutory law level. Still, children's right to family life is not always explicitly discussed or given proper attention in the legislation, in the reasoning of the law or in case law. I do believe the constitutionalizing, and, in particular, the interpretation that sections 102 and 104 are interlinked and must be interpreted in the light of each other has the potential to strengthen children's rights in this matter. As discussed, it is not possible to argue that the constitutionalizing has had an essential legal effect, up to now. Still, some positive elements can be found, but this is not at all consistent. The ECtHR judgment in the Janson case, and the minority dissenting opinion in the Strand Lobben case, highlights the need for Norwegian case law to give proper attention to children's right to family life. In-depth examination of the child's best interests is not enough. Children's rights to respect for family life must also be examined and sufficiently weighed. If this is consistently done, I guess it does not matter if the change is influenced or caused by the constitutionalizing or not.

\section{References}

Arnfinn Bårdsen, 'Interpreting the Norwegian Bill of Rights' (Annual Seminar on Comparative Constitutionalism, Oslo, November 2016) <https://www.domstol .no/en/Enkelt-domstol/-norges-hoyesterett/Articles/articles-and-speeches-2016/ interpreting-the-new-norwegian-bill-of-rights/> accessed 25 January 2019. 
Dokument 16 (2011-2012) Rapport til Stortingets presidentskap fra Menneskerettighetsutvalget om menneskerettigheter i Grunnloven, avgitt 19. desember 2011, (Dok. 16). <https://www.stortinget.no/Global/pdf/Dokumentserien/2O11-2012/dok16-201112 .pdf $>$ accessed 25 January 2019.

Haugli T, 'Constitutional Rights for Children in Norway' in Trude Haugli and others (eds), Children's Constitutional Rights in the Nordic Countries (Brill 2019).

Innst. 186 S (2013-2014) Innstilling til Stortinget fra Kontroll- og konstitusjonskomiteen.

Innst.195 L (2016-2017) Innstilling fra familie- og kulturkomiteen om Endringer i barnelova mv. (likestilt foreldreskap).

Innst.359 L (2016-2017) Innstilling fra familie- og kulturkomiteen om Lov om adopsjon (adopsjonsloven).

NOU 2014:9 Ny adopsjonslov.

NOU 2016:16 Ny barnevernslov. Sikring av barnets rett til omsorg og beskyttelse.

Prop.88 L (2016-2017) Lov om adopsjon (adopsjonsloven).

Prop.161 L (2015-2016) Endringer i barnelova mv. (likestilt foreldreskap).

Sandberg K, 'Best interests of the child in the Norwegian Constitution' in Trude Haugli and others (eds), Children's Constitutional Rights in the Nordic Countries (Brill 2019).

UN Committee on the rights of the child, General comment No. 14 (2013) on the right of the child to have his or her best interests taken as a primary consideration (art 3, para 1) (29 May 2013) CRC/C/GC/14. 